\title{
Beyond Beauty or Urban Design of Responsibility
}

\author{
Thorsten Bürklin \\ th.buerklin@fh-muenster.de | (D) https://orcid.org/0000-0003-4822-0320 \\ Münster School of Architecture (MSA), Department of History and Theory \\ of Architecture
}

Michael Peterek

michael.peterek@fb1.fra-uas.de | (D) https://orcid.org/0000-0003-1057-5425

Frankfurt University of Applied Sciences (FRA-UAS), Global Urbanisation

Research Team

Scientific Editor: Mateusz Gyurkovich, Cracow University of Technology

Technical Editor: Matgorzata Mazur, Cracow University of Technology Press

Language Verification: Timothy Churcher, Merlin Language Services

Typesetting: Anna Basista, Cracow

University of Technology Press

Received: October 6, 2021

Accepted: November 25, 2021

Copyright: ๑ 2021 Bürklin, Peterek. This is an open access article distributed under the terms of the Creative Commons Attribution License, which permits unrestricted use, distribution, and reproduction in any medium, provided the original author and source are credited.

Data Availability Statement: All relevant data are within the paper and its Supporting Information files.

Competing interests: The authors have declared that no competing interests exist.

Citation: Bürklin, T., Peterek, M. (2021). Beyond Beauty or Urban Design of Responsibility. Technical Transactions: e2021020. https://doi.org/10.37705/ TechTrans/e2021020

\begin{abstract}
In recent years, urban spaces all over the world have been effectively staged, sometimes all too obviously, and urban design has often concentrated on the implementation of "beautiful" lighthouse projects and globally oriented lifestyle urbanism. However, beauty - also in the broader sense of a beautiful experience - cannot be an end in itself in urban planning. An urban design of responsibility has to be committed to all residents and address the pressing challenges of our time, for example: the almost unlimited consumption of land, water and energy; floods and heatwaves due to climate change; lack of decent living conditions for large parts of the population. Against this background, five strategic guidelines for the integrated and responsible planning of our cities have been developed. These include "comprehensive" and integrated neighbourhoods, a mobility turnaround, interconnected blue and green infrastructure, a circular resource economy and space sharing, and the exploitation of the opportunities of digitalisation for a social and ecological city.
\end{abstract}

Keywords: urban design, integrated urban planning, sustainable cities, lifestyle urbanism, urban space 


\section{Introduction: "I prefer it beautiful"1 - Urban Design as Spatial Art}

In recent years, urban spaces all over the world have been effectively staged, sometimes all too obviously. In many places, urban design has concentrated on the effective implementation of lighthouse projects that have a supra-regional or even international impact. As a result of Bilbao's teaching, architecture in Los Angeles, Beijing, Hamburg, Dubai, Abu Dhabi and other places has been and continues to be brought into play worldwide as a media attractor. Those who want to position themselves in the international competition between cities have to promote the iconic. ${ }^{2}$

Elsewhere, plazas and open spaces are being created as islands of experience for sophisticated city dwellers. ${ }^{3}$ This development, among others, has origins on the Iberian peninsula, where the design of new public squares of the "cosmopolitan city" of Barcelona - in the face of desolate modern urban deserts - has met with the enthusiastic interest of a public hungry for personal identification and interaction. In the course of this, the pre-industrial city - under the influence of post-modern criticism - made a comeback in the form of Italian models with their characteristic squares and urban monuments (Rossi, 1966), at least in fragments and images. ${ }^{4}$ In accordance with this, Camillo Sitte's urban aesthetics - which still dated from the $19^{\text {th }}$ century - were highly popular (Sitte, 1909). Phenomenological studies that addressed perception in (urban) space served the desired images and the (supposed) demands of the time (cf. among others Janson \& Bürklin, 2002).

The creativity demonstrated here by means of aesthetic seduction promotes the location. It attracts visitors and companies, their employees and contacts. Forward-looking policies care about creative urban potentials, and as Charles Landry (2008) pointed out with regard to successful urban development concepts: "Cultural resources are the raw materials of the city and its value base; its assets replacing coal, steel or gold. Creativity is the method of exploiting these resources and helping them grow" (Landry, 2008: 7). ${ }^{5}$ This is to lure innovative industries and service providers. To achieve this, more than a functioning infrastructure is needed. It is about lifestyle, about personal life projects, the realisation of which a highly mobile and, according to their own understanding, dynamic clientele expects in a supposedly creative, cosmopolitan and continuously changing ambience ${ }^{6}$; it is about one or more attitudes to life, about the displayed "uniqueness and exceptionality that has become a paradoxical social expectation to achieve [...]" (Reckwitz, 2021: 9)7. Urban planning engages in this sense (Landry, 2008) ${ }^{8}$. One can think of countless international projects, such as the early initiation of the Museum Embankment in Frankfurt am Main or the upgrading of the waterfront around the area of the European Central Bank (Figure 1).

All verbatim quotes from sources in German have been translated into English by the authors.

Even smaller cities, such as Herford in the province of Lower Saxony, wanted to participate in the Bilbao effect (or Gehry effect) with a Gehry building, the MARTa (Hofmann \& König, 2011).

Literally, this has happened in New York, where an artificial island, the "Little Island", designed by Thomas Heatherwick and financed mainly by Diana von Furstenberg and Barry Diller, has just opened to visitors (Linder, 2021: 20).

4 If Henri Lefebvre's statement is true that every society produces its own space (Lefebvre, 2000: 65), then it quickly becomes clear why these adoptions could only be realised in fragments and as pictorial adaptations. It was because the postmodern actors were aware of the very different historical situation in which they were acting that irony played such a significant role in the works of the time.

$5 \quad$ And further: "In a period of attention deficit when people have little mental space, urban leaders need to know how to orchestrate 'the iconic' to keep their city in the forefront. Cities now compete by projecting themselves 'iconically' and success can depend upon how their 'iconics' are orchestrated. Icons are projects or initiatives that are powerfully self-explanatory, jolt the imagination, surprise, challenge and raise expectations" (Landry, 2008: xliii).

6 Among the soft location factors Landry (2008: xliii) counts: iconics, design consciousness, eco-awareness, artistic thinking, atmospherics and experience, associational richness and resonance creation, cultural depth, networking capacity, communication and language skills.

And further: "In the mode of singularisation, life is not simply lived, it is curated" (Reckwitz, 2021: 9).

8 See more: Landry, 2008: xli/xlii: Activating Creative Assets, and Landry, 2008: xlii-xlviii: Orchestrating Soft Assets. 


\section{a:: technical

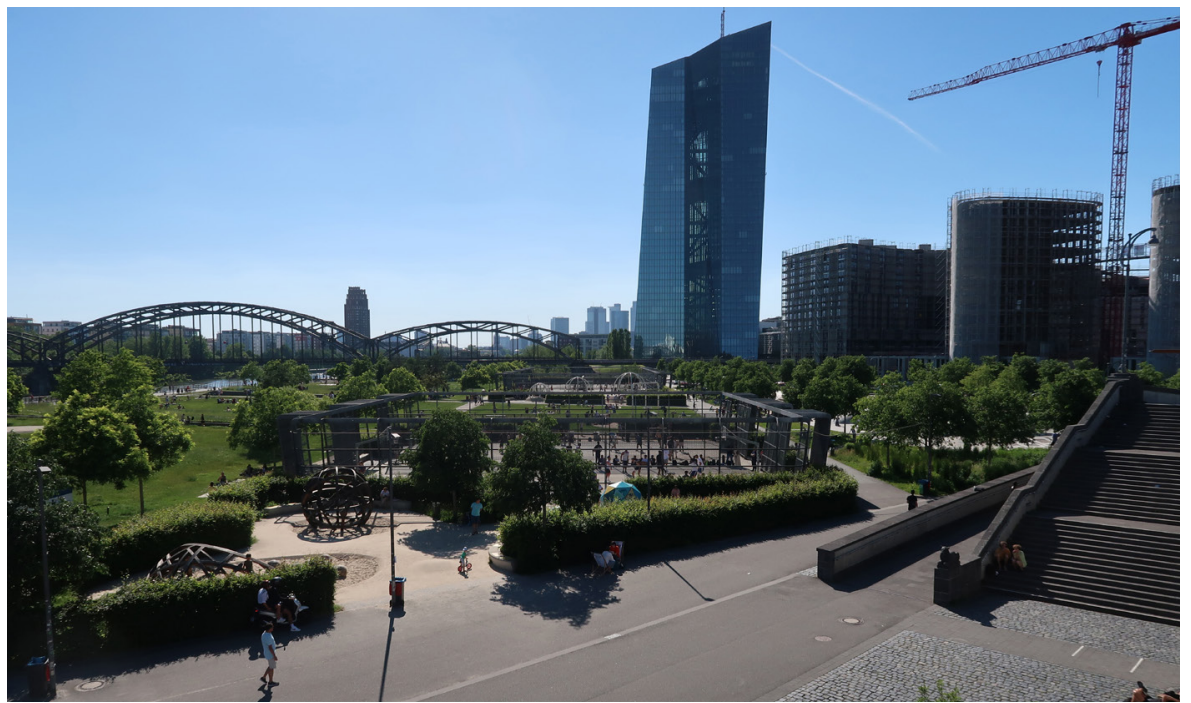

Fig. 1. European Central Bank with upgraded waterfront in Frankfurt am Main (c) Bürklin

As "individual" and differentiated or singularised as the actors and residents of this booming lifestyle urbanism may feel and act, in many places, in private as well as in public space, the lifestyles converge as a rather superficial consensus: "I prefer it beautiful" - as a well-known home staging advertisement (especially with a view to better property marketing opportunities) says it straight from the heart of people (Cornelia Augustin Home Staging, 2021). Who from the centre of the experience society could not agree with this statement beyond the economic lure? The inward-looking individual, preoccupied with the "project of a beautiful life" (Schulze, 2000: 40)9 , will not hesitate for a moment, following Gerhard Schulze's imperative for action from the 1990s: “Experience your life!" (Schulze, 2000: 59). Urban design as spatial art serves this desire in the sense of city marketing that meets common expectations (Figure 2). As a rule, the creative will of architects and urban planners should have no objections when it comes to realising something beautiful in their work for both city residents and visitors. This should be especially true when there is universal agreement about it. The intensity with which the public squares and parks created in recent years have been accepted, not only during the Corona pandemic, certainly allows this conclusion to be drawn.

Obviously, planners have learned from the mistakes of the past, in which modern urban planning measures were implemented ideologically in the sense of the assumed needs of the inhabitants, but in fact over their heads. In the

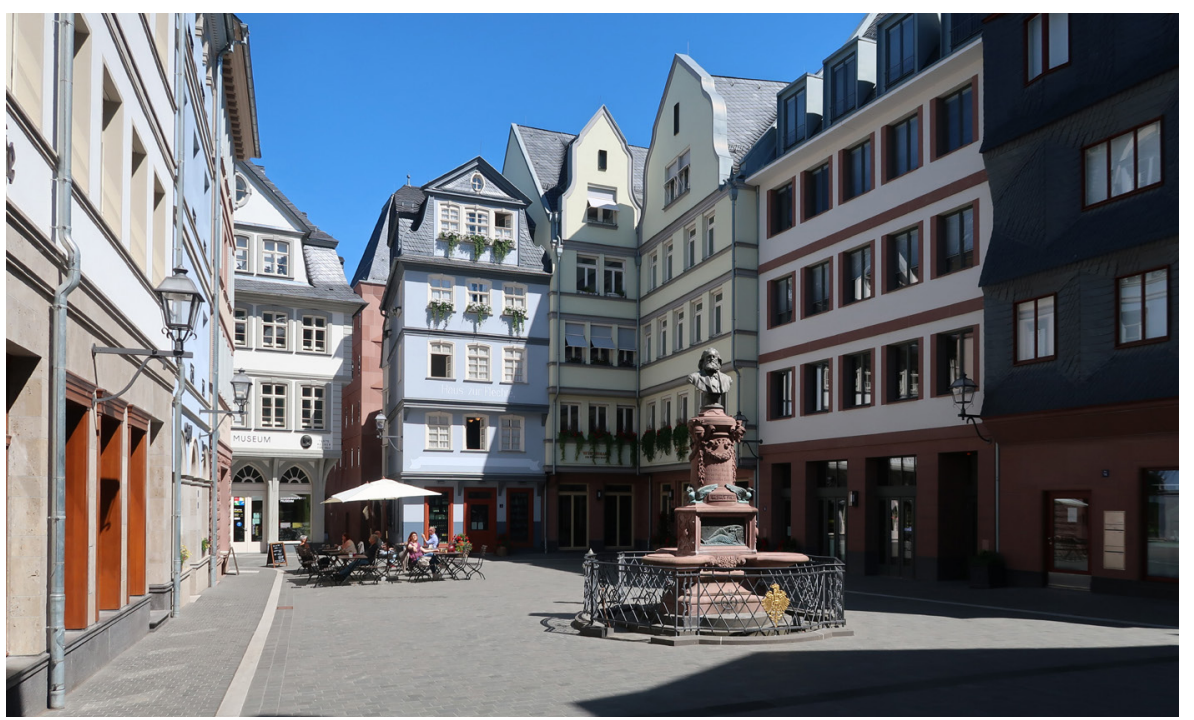
1970s, Henri Lefebvre's criticism still distinguished between the ideas and presentations of planners, politicians and decision-makers (représentation de l'espace) and the spaces of representation (espaces de représentation) as well as the everyday practices (pratique de l'espace) of the inhabitants, i.e. between the planned (conçu) and the lived (vécu) as well as the perceived (perçu) spaces (Lefebvre, 2000: 48-57). Supposedly universal standards of urban design applicable to every situation (and every cultural, social or climatic feature) had created an almost insurmountable ideological divide. On the one hand - in Michel de Certeau's terminology

Fig. 2. The "beautiful" reconstruction of the new Frankfurt Old Town @ Bürklin
- strategies decided the shape of (urban) spaces; on the other hand, the so-called tactics (of the inhabitants) appropriated the space in their own way as needed, even contrary to the original assumptions of architects, urban planners and politicians (de Certeau, 1990: 57-63). Professional narrow-mindedness was contrasted with individual fantasy born of necessity. 


\section{口::: technical

At first glance, this contrast became harmony. Looking at the new places of experience of the creative city, it seems as if the wishes have been read from the lips of the city dwellers. Urban planning that sees itself as spatial (and experiential) art provides cafés, leisure facilities, skating rinks, sunbathing lawns, plus a (not overwhelming) mix of urbanity and culture that is open to all who want to share in the attitude to life that is promised there. A cosmopolitan, diverse society seems to realise the multifunctional and pluri-relational spaces that correspond to it in these places. While conflicts of interest have superficially disappeared, important questions remain unanswered behind

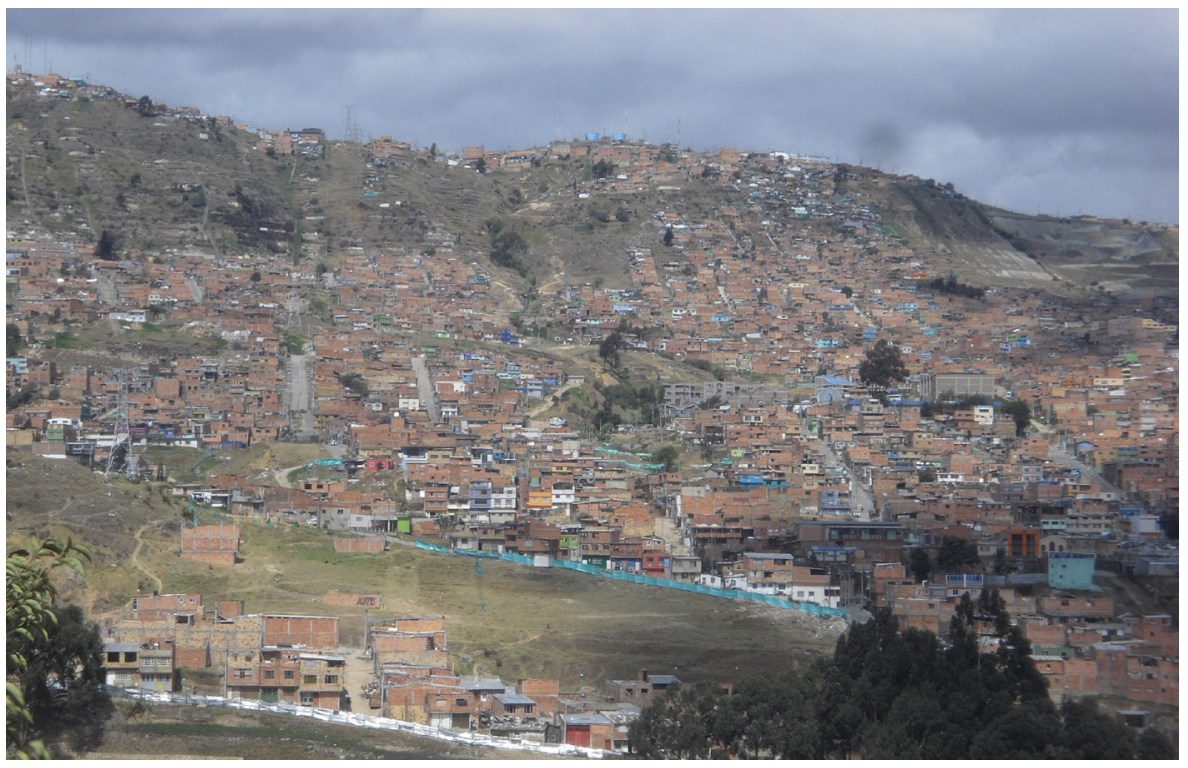
the scenes - or even just a street corner away. The contrast of strategies and tactics still exists if one shifts one's gaze away from the mobile urban population and the worlds of experience they inhabit and turns, for example, to the gentrification of hip urban neighbourhoods

Fig. 3. The urban reality in many regions of the world. Informal growth of Bogotá, Colombia (C) Peterek (Avan, 2020; Mühl, 2021b).

It is also worrying that under the conditions of neoliberal deregulation, questions of social cohesion, both at the urban level and within neighbourhoods, can only be discussed on an abstract - a political/planning/technical ${ }^{10}$ - level because personal direct contact across social boundaries hardly exists as a rule (and is also little sought after). Despite Fridays for Future and the omnipresence of the climate crisis in political and academic discussions as well as in advertising, there is no need to have any illusions about the (sometimes disastrous) consequences of the "imperial mode of living" (Brand \& Wissen, 2021) ${ }^{11}$ for nature, the environment, people with lower incomes, for the hinterland of the richer centres, and for many other parts of the world (Figure 3$)^{12}$.

\section{Urban Design of Responsibility}

Beauty - also in the broader sense of a beautiful experience - cannot be an end in itself in urban planning. In addition, urban planning must once again be understood as a discipline that is committed to all city residents, and also to the surrounding areas - not primarily to city marketing (which is certainly important in view of international competition). Many of the resulting challenges are not new. However, the need for action at both the micro and macro levels has long become more acute internationally because they have been addressed far too rarely in practice for too long. The interested (professional) public and the readers of the features pages of the press have long been aware that there is an urgent need for action with regard to many aspects of sustainability. Relating

10 In this sense, Lefebvre's concept of abstract space (espace abstrait) remains up-to-date (Lefebvre, 2000: 60-61 and 65).

11 "To put it pointedly: unsustainability is a very practical fact that is mostly lived unconsciously. But living "unconsciously" does not mean that the imperial mode of living is not connected to multiple intentional strategies for its continuation. [...] Activities and decisions are embedded in a societal context that allows them to be seen as rational or normal, a context inscribed into the subjects who carry out or make these decisions" (Brand \& Wissen, 2021: 45).

12 Cf. Mühl, 2021a: 11: "Surveys on environmental awareness and behaviour impressively illustrate our inherent inertia: Reliably, more than eighty percent agree with the statement that we need to take more decisive action in the fight against climate change. At the same time, however, the majority of these supposedly environmentally concerned people like to fly on holiday and prefer to take the car instead of public transport." 


\section{a:: technical

to the seventeen Sustainable Development Goals (SDGs) developed by the UN (United Nations, 2015), the term should be adopted in urban planning in the sense of the breadth of contents formulated there. In addition to aspects of climate justice, the UN addresses issues of health and equal opportunities, gender justice and the prevention of economic and social inequality. Goals 9 and 11 of the SDGs directly address urban planning issues in particular. They deal with "Industry, Innovation and Infrastructure" and with "Sustainable Cities and Communities" (United Nations, 2015).

The framework for action of an urbanism of responsibility would thus be the horizon of man, which threatens to disappear without the commitment of care for the environment - people, fauna and flora, nature in general, the climate - and also social peace (Bürklin, Peterek \& Reichardt, 2021). The current developments of the Corona pandemic have directly shown us the vulnerability of our human situation. Once again, existential questions are being raised that require a rethink and new actions in both architecture and urban planning.

Throughout history, there have always been decisive turning points in the urban planning profession. A hundred years ago, modernism was inspired by the desire to realise a better city in light of the inadequate living conditions in the cities of the industrial age. The goal was to guarantee light, air and sun for everyone to live and work in. This task remains dramatically topical considering inadequate living conditions worldwide (Bürklin, Peterek \& Reichardt, 2021). Almost 50 years ago, postmodernism was concerned with establishing attractive urban spaces beyond healthy living. The goal was to regain urban spaces that could be perceived and experienced and also to interweave different uses and increase the quality of public space. Such an effort to create lively and at the same time beautiful and identity-building urban spaces has decisively shaped our actions in recent decades. All these remain legitimate goals and demands, but they alone are no longer sufficient. Today, further demands must be added to these.

Once again, we need a different city, with an expanded concept of beauty and architects and urban planners have a pioneering role to play. They must develop new perspectives and visions for urban planning that take responsibility for the most pressing questions of our time. Planning is in demand when it comes to

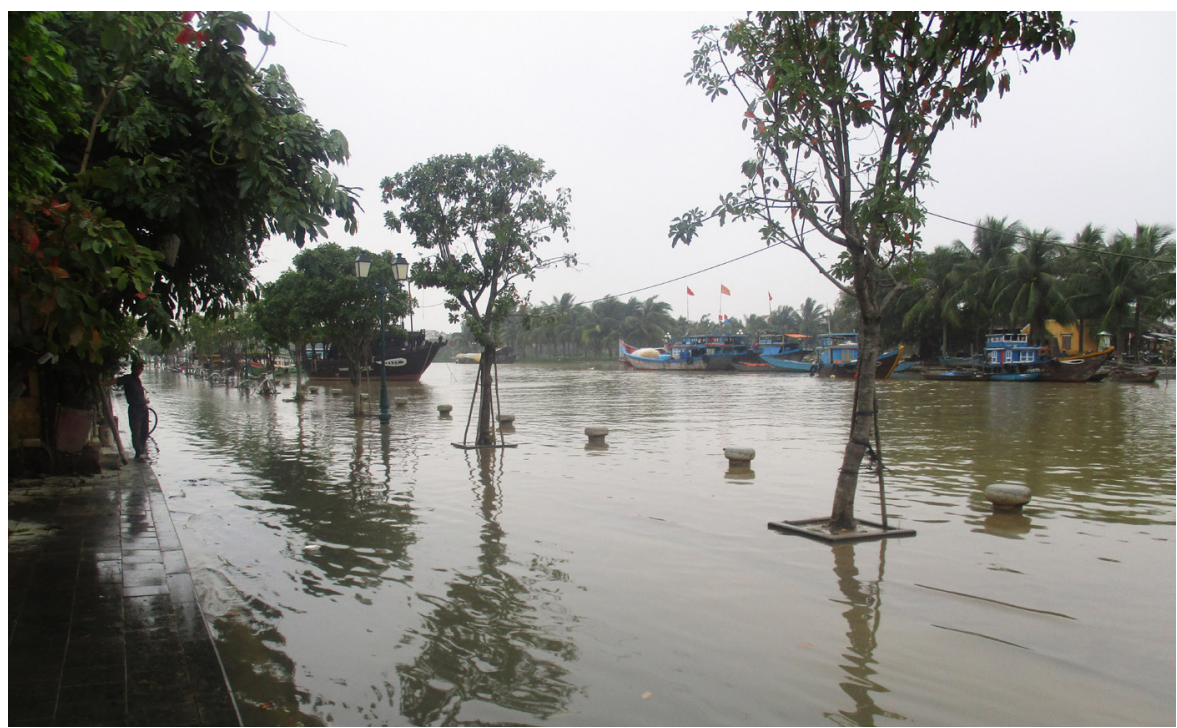
optimising the consumption of space, water and energy. It is precisely global urbanisation and unrestrained urban growth in many regions of the world that continues to fuel the waste of resources to this day. The resulting climate change and the natural disasters that occur in the course of this are articulated particularly dramatically in many agglomerations worldwide (Figure 4). However, the countryside is also affected due to floods and heat waves as well as the resulting crop failures and famines. In addition, the need for a socially acceptable urban development is becoming increasingly apparent - not only in poorer countries but also in the centres of prosperity in Europe, where affordable housing

Fig. 4. Flooding of the World Heritage City of Hoi An, Vietnam @ Peterek has become a scarce commodity. After all, it is the city that has to offer more and more people - not only those who are mobile and creative - spaces where opportunities for development of both the individual and the community are to be made possible beyond the described "experience economy".

Urban planning can only assume such responsibility through the integration of all other disciplines involved in the design of urban spaces. For too long, we 
have thought and acted in the separate silos of our different professions and departments: here the architects, there the traffic engineers, and then the infrastructure planners, the landscape architects and others - with neatly separated responsibilities, competences and concepts. In order to tackle the challenges of the present, however, the networking of expert knowledge and the resulting common strategic approach is necessary, which brings together the diversity of all disciplines involved in a holistic and integrative planning of our spatial environment. Digital tools offer the possibility of translating complex parameters of spatial, infrastructural and social organisation into an "individualised" local spatial planning strategy related to the street and the neighbourhood level which at the same time satisfies overarching global requirements.

\section{Strategic Guidelines for Future Urban Planning}

The integrated and responsible planning and design of our cities would strengthen their existing potentials. At the same time, it would focus attention on those developments that lead to social injustice and dislocation. Planning strategies would be guided by climate-friendly issues. The following five strategic guidelines provide an outlook on central issues, although the scope of this paper prevents them from being exhaustively explained here.

\subsection{Comprehensive Neighbourhoods}

The developments of the pandemic in recent months have brought home the importance of "comprehensive" neighbourhoods as the living spaces of everyday life. People have discovered the quality - and also the massive deficits - of their "local space" and their living environment on the doorstep, including public and green spaces. Since the 1960s, starting with Kevin Lynch's Image of the City (Lynch, 1960) and (in Europe) Aldo Rossi's The Architecture of the City (Rossi, 1966), the discussion has revolved around the task of creating spaces of individual and collective identity. As a late echo - and in view of the supposed globalisation phenomena such as internationally converging spaces of living, work and leisure - the concept of "Heimat" (home) became the centre of numerous discussions, especially in German-speaking areas. ${ }^{13}$ The migration movements of 2015 gave these topics an even greater complexity. Since then, it has no longer been possible to turn a blind eye to the task of the social and spatial integration of refugees, even in urban planning.

The growing urban regions must be transformed into a system of interconnected, compact and integrated centres and city districts. The motto in future must be "as much locally as possible". Social neighbourhoods, spatial proximity, a mix of functions, structural diversity - all these are important resilience factors in both the social and climatic sense that must now be strengthened in our cities. Only within the framework of a "city of short distances" or a "region of short distances" can spaces be created that offer ample individual and collective opportunities for all residents (Figure 5). On the one hand, such demands for urban compactness, diversity and integration need to be applied in the construction of new city extensions, where these are still needed. And on the other side, these requirements have to be considered in the development and socio-ecological transformation of the large settlements and housing stocks of post-war modernism. In Germany, for example, around $40 \%$ of today's housing stock was built between 1949 and 1978, in largely monofunctional and poorly

13 See e.g. the conferences "Heimat planen. Heimat bauen. Siedlungen als Kulturerbe und Lebensraum", organised by the Bund Heimat und Umwelt in Deutschland (BHU), the Schwäbischer Heimatbund and the State Office for the Preservation of Historical Monuments in Baden-Württemberg, from 14 to 16 October 2014 at three different locations in Stuttgart, as well as "Heimat - Raum - Hirn. Neurowissenschaftliche Erkenntnisse, Architektur und Stadtplanung“, held by the Evangelische Akademie Frankfurt am Main on 20 November 2014, at the FIZ Frankfurter Innovationszentrum Conference Lab, Frankfurt am Main, Riedberg. 


\section{口::: technical

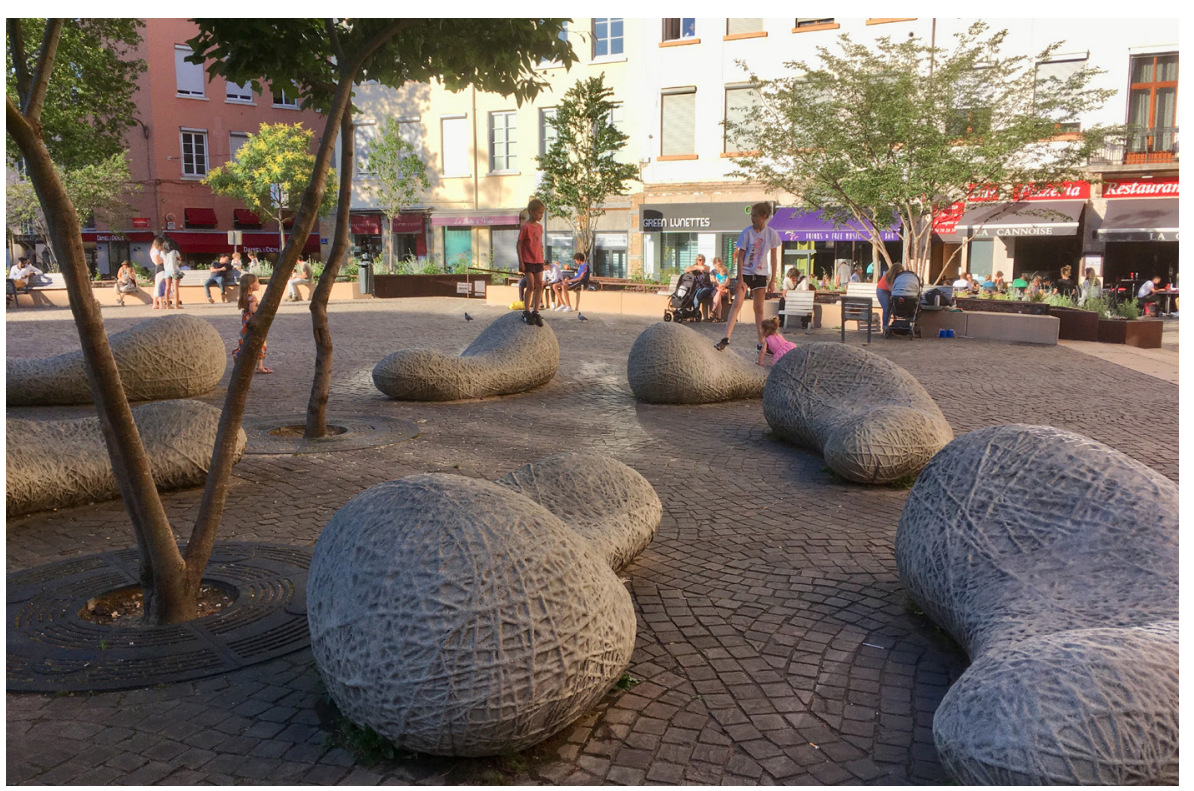

integrated settlement structures. And last but not least, it is also a question of stabilising and converting inner cities and city centre areas, the problems of which have been known for some time and have become much clearer in the spotlight of the pandemic. The one-dimensionality of many city centres must be broken up in order to create not only new hybrid places for communication, culture and education, gastronomy, co-working and urban production but also new forms of inner-city living.

What is needed here is a planning and political integration of different fields that are of fundamental importance for living and working. It is not enough to provide recreational spaces if a housing market open to all

Fig. 5. A lively district of short distances in Lyon ๔ Peterek

population groups is not provided at the same time. Similarly, it is not possible to focus on climate-friendly planning if it is not designed in a socially acceptable way. However, as Ingrid Breckner (2018) points out, there is still a great need for improvement in this political-operational field: "The art of sustainable action consists in interlocking the respective desired ecological, economic and social aspects of sustainability in such a way that inequalities in access to urban living conditions are avoided as far as possible. For this broad spectrum of central challenges in urban development, there are, despite diverse research efforts, still no universal solutions."

\subsection{Mobility Turnaround}

The mobility turnaround, which has been slow thus far, must be integrated into urban development as a top priority. In many cities, the Corona lockdown has led to test sites of a new mobility. Pop-up cycle paths as well as car-free zones were set up at short notice - measures that could not have been implemented under

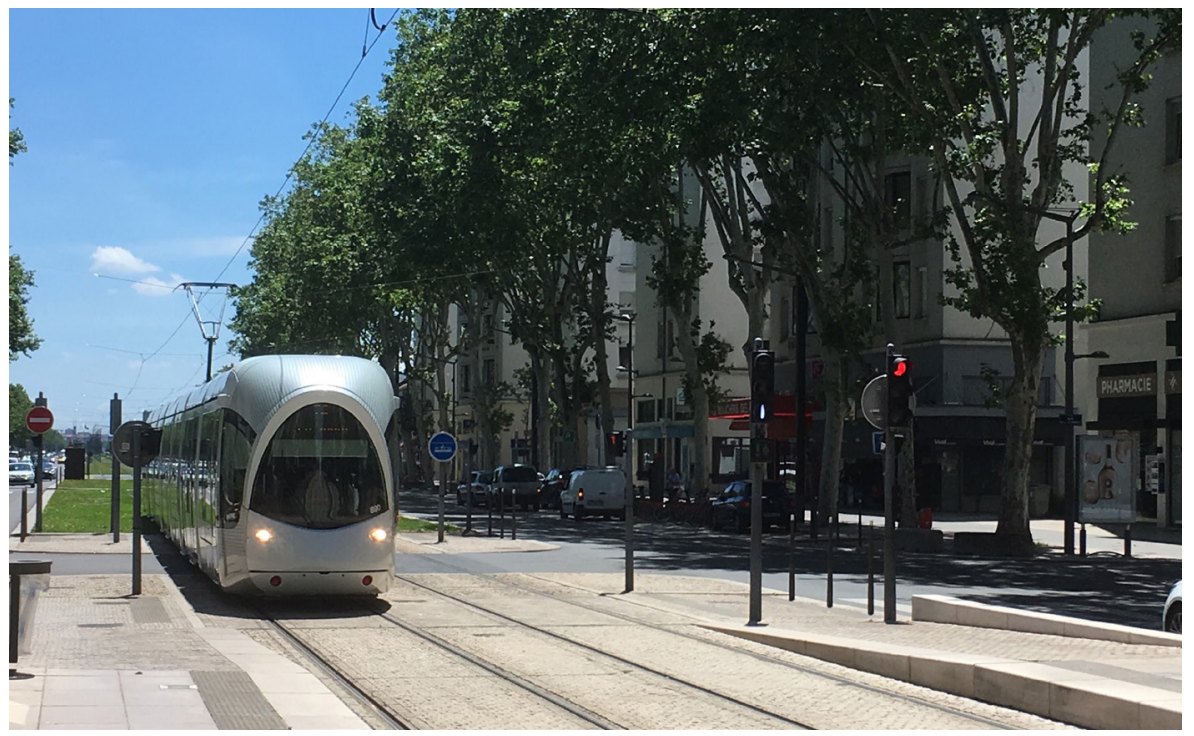
normal circumstances or only with great resistance ${ }^{14}$. These experiences can be built upon and the end of the city dominated by the automobile can be shaped (Figure 6).

Compact, diverse and integrated urban districts contribute to a reduced need for mobility by themselves. New options of climate-friendly mobility, such as sharing models, micro- and e-mobility, are receiving attention. In the future, they must be implemented in networked systems for the neighbourhood, the city and the region. The achievements of digitalisation can play an important role here, as the increasing availability of "mobility as a service" (MaaS) already shows today. If one also
Fig. 6. Towards a more sustainable mobility (C) Peterek
14 Consider the temporary closure of the northern bank of the Main in the inner city area of Frankfurt to motor traffic, which was in any case limited in time and ultimately not extended despite a citizens' petition (Leclerc, 2020). 
takes into account that on an average day in Germany about $40 \%$ of all cars are not used (Nobis \& Kuhnimhof, 2018), it becomes clear what potential (e.g. in the form of additionally available space reserves) a consistent mobility turnaround would also bring for urban design.

At the political macro level, the corresponding goals have already been formulated. In the context of the European Green Deal drafted by the European Commission, the negative environmental impacts caused by freight transport are to be reduced via multimodal transport solutions (Communication from the Commission, 2019). More loads would then be transported by ship and rail instead of by road. Cities and urban regions can benefit from this. Noise reduction, a reduction in land sealing and a deconstruction of the deformed landscape serve to enhance local and regional value. A hundred years ago, modernism was already inspired by the realisation of a healthy living environment. The task of guaranteeing light, (clean) air and sun for all people remains a central challenge in times of climate change and often extreme fine dust pollution.

\subsection{Green and Blue Infrastructures}

With heavy rainfall, storms and periods of extreme heat or cold, climate change is creating environmental conditions, the effects of which we are feeling increasingly clearly and for which neither our urban spaces nor their inhabitants are prepared.

The measures taken by urban planners remain far too restrained. Yet global urbanisation and urban sprawl are central factors in climate change. Hans Joachim Schellnhuber, who was head of the Potsdam Institute for Climate Research until 2018, is now advocating a radical rethink in the building sector: Around forty percent of the greenhouse gases emitted globally come from the construction and operation of buildings and infrastructure. In western industrialised countries, more than half of the total waste mass is generated by construction and demolition. In Germany, about 45 hectares of near-natural landscape are converted into settlement and transport areas every day. Politics and business are hesitantly beginning to address this factor, but have so far failed to develop a holistic concept (Schellnhuber, 2021: 9).

In Schellnhuber's vision, the cities of the future are to be built of wood instead of concrete, which would radically reduce the $\mathrm{CO}_{2}$ emissions of the construction sector.

Urban planning can and should go a few steps further. Local conditions of climate, environment and nature are still rarely taken into account. To counter climate change and at the same time create attractive and resilient spaces, our cities must become even greener. Parks, green streets and squares, even roofs and facades reduce sealing as well as overheating of the city (Figure 7). However, caution must be exercised.

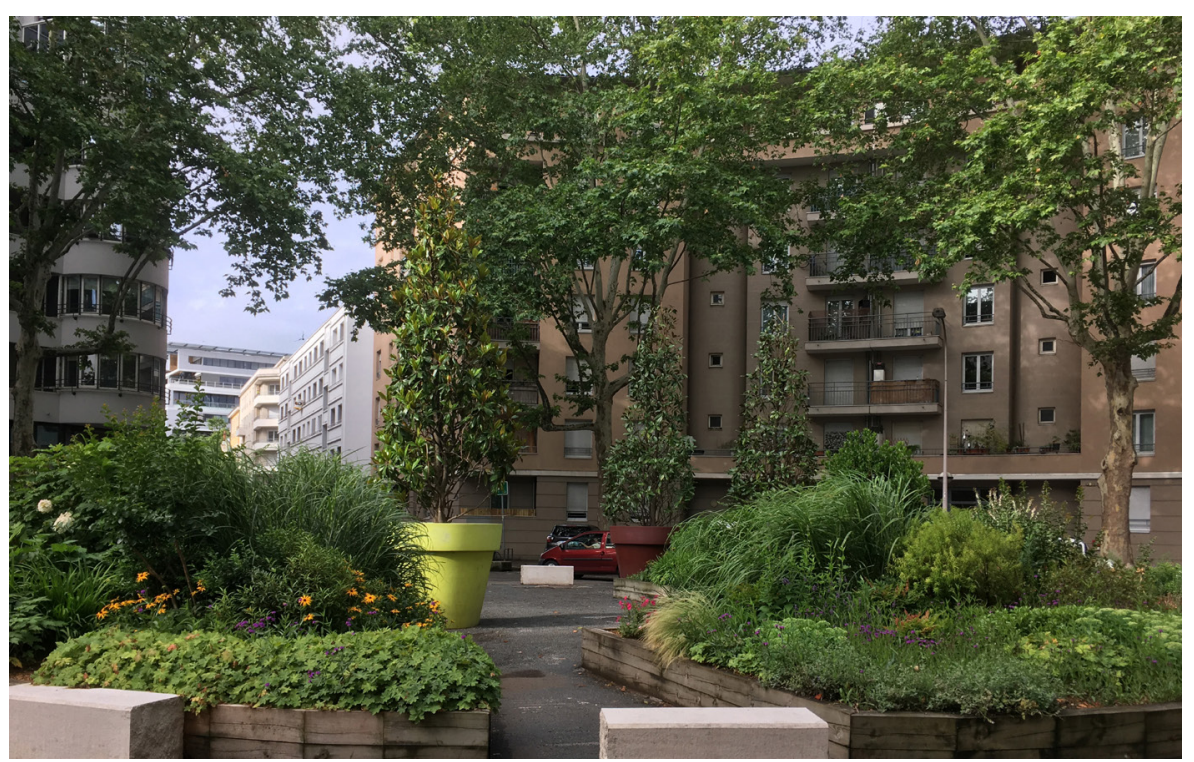

In this case too, it is not a matter of just placing fashionable greenery in squares or on façades. For example, it is emphasised that the approximately 800 trees, 15,000 perennials and 5,000 shrubs of the Bosco verticale designed by Stefano Boeri for Milan absorb a large amount of $\mathrm{CO}_{2}$. At the same time, however, doubts are being raised as to whether the increased energy and material consumption of the supporting structure, which has to be larger due to the planting, and the infrastructure for irrigation and maintenance do not far exceed the savings effects (Cuda, 2021; Seghetti, 2020; Klöckner, 2013). Where possible, therefore, 
low-tech solutions that require less care and maintenance should be used, as is the case elsewhere.

In accordance with the above point, water must be integrated into urban planning. Water-sensitive urban design (WSUD), such as the concept of "sponge cities", increases resilience to heavy rainfall and flooding. Such measures temper the urban climate and increase the quality of the living environment. Many cities are already showing innovative solutions in linking green, blue and built spaces, as proven with examples from Singapore, Belgium, the Netherlands, Copenhagen, Australia and others.

\subsection{Circular Economy and "Space Sharing"}

Architecture and urban design have to minimise the consumption of resources as well as the production, supply and waste chains that are necessary for both the production and the deconstruction of our physical environment. Therefore, integrated resource cycles must also be developed in the city. To this end, regionally available materials and components must be used as far as possible, such as the increased use of wood as a building material, including hybrid constructions, as well as the recycling and consistent reuse of building materials: "Ideally, transport routes should be kept short and the reused material should come from the respective region. In this context, there is also talk of 'urban mining'. The 'old' city is considered the material storehouse of the city of the future" (Welzbacher, 2021: 19).

Integrated cycles of urban supply and disposal structures - such as rainwater and service water recycling for use in green spaces or in urban agriculture, the conversion of waste into energy, etc. - can identify and implement synergies between the different infrastructure sectors. Targeted action in this area can also make a decisive contribution to resource efficiency. Only when trans-sectoral cycles become binding as a standard at all levels of planning and implementation can architects and urban planners fulfil their responsibility for reducing the climate and environmental crisis.

A compact and creative interweaving of urban functions minimises land consumption. Intelligent "space sharing" must be a guiding goal at both the urban and the single building level. The forward-looking location of buildings as well as the space-saving and traffic-reducing organisation of urban space are the prerequisites for a convertible (re)use and thus long-term adaptability and resilience of our urban structures.

\subsection{Opportunities of Digitalisation for an Ecological and Social City}

The existing possibilities of digitalisation are demonstrating a growing influence on the design of our everyday living and working spaces. The digitally networked mobility options have already been mentioned. Experiences from the recent massive "home office" experiment also show consequential effects and will change our urban environments.

A "smart city" must go beyond the claim of a merely technologically optimised city. Digitalisation must not be left to the private-sector marketing of optimised technical processes and services. Municipalities and urban planning have to take responsibility here. In accordance with this, the city of Vienna formulates its Smart City strategy as follows: "Through comprehensive social and technical innovations, the city wants to ensure the highest quality of life for all Viennese while conserving resources as much as possible. The Smart City Vienna pursues the vision of a city in which it is possible to live well without this being at the expense of the environment and thus of future generations, precisely because it uses natural resources carefully and responsibly. [...] A smart city in Vienna's understanding is a city that never loses sight of the human scale, that focuses on the needs of its residents in their diverse lifestyles and in doing so opens up equal development opportunities for all people" (Stadt Wien, n.d.). 
The availability of immense amounts of data, as it is given today in an unprecedented way, means both opportunity and risk. For urban planning, it demands ecological and social responsibility at the same time. New technologies offer great opportunities, for example, to understand, optimise and efficiently control resource and land use cycles. Openly available data, software and digital platforms can contribute to collaborative urban planning and the design of a city oriented towards the common good. They allow new forms of participation for residents and a quick visualisation of alternative scenarios and projects.

\section{Conclusion: Strategies and Tactics}

We have to face the consequences of our concrete actions in planning and building our cities. The strategic guidelines mentioned must be realised in harmony with the protection of nature and the specific regional, climatic and socio-cultural conditions of the given case. The claim to universal solutions that are valid in every place in the world, as once postulated by Le Corbusier with the Radiant City, can no longer do justice to today's challenges.

Conflicts will also be unavoidable in the future. Michel de Certeau's duality of strategies and tactics will continue to accompany planning, as it always intervenes in the spheres of life of a multitude of people with different needs and interests. In any case, caution is called for. For example, digitalisation has not yet led to the democratisation of existing power relations in our urban societies. In general, competing planning goals sometimes prove to be contradictory and difficult to reconcile, as Ingrid Breckner (2018) notes: "Nevertheless, the practical implementation of social compatibility in sustainable urban development efforts, even in prosperous societies, has so far proved to be more of a patchwork than a convincing, long-term effective strategy for action." The focus will be on developing instruments for socially compatible, climate-friendly and financially viable planning and design (Figure 8).

This again addresses the role of architects and urban planners. Obviously, the challenges outlined exceed the scope of action and competence of one or a few actors. All too often, they themselves become tacticians in order to be able to stand up to economic, political, social and planning law resistance. It is precisely for this reason that an open discussion is needed that acquires a political dimension and power in order to be able to implement the necessary goals of future planning.

\section{"I prefer it beautiful" - this guiding} principle of a late capitalist experience society should be reconsidered and revised. Urban planning of responsibility and integration that fulfils the central demands of all people to enable them to live and work in a healthy and dignified way will always produce a "beautiful" city in a comprehensive sense. However, this would be a city in which the inhabitants feel comfortable, with which they identify and which takes into account the concerns of nature and the climate.

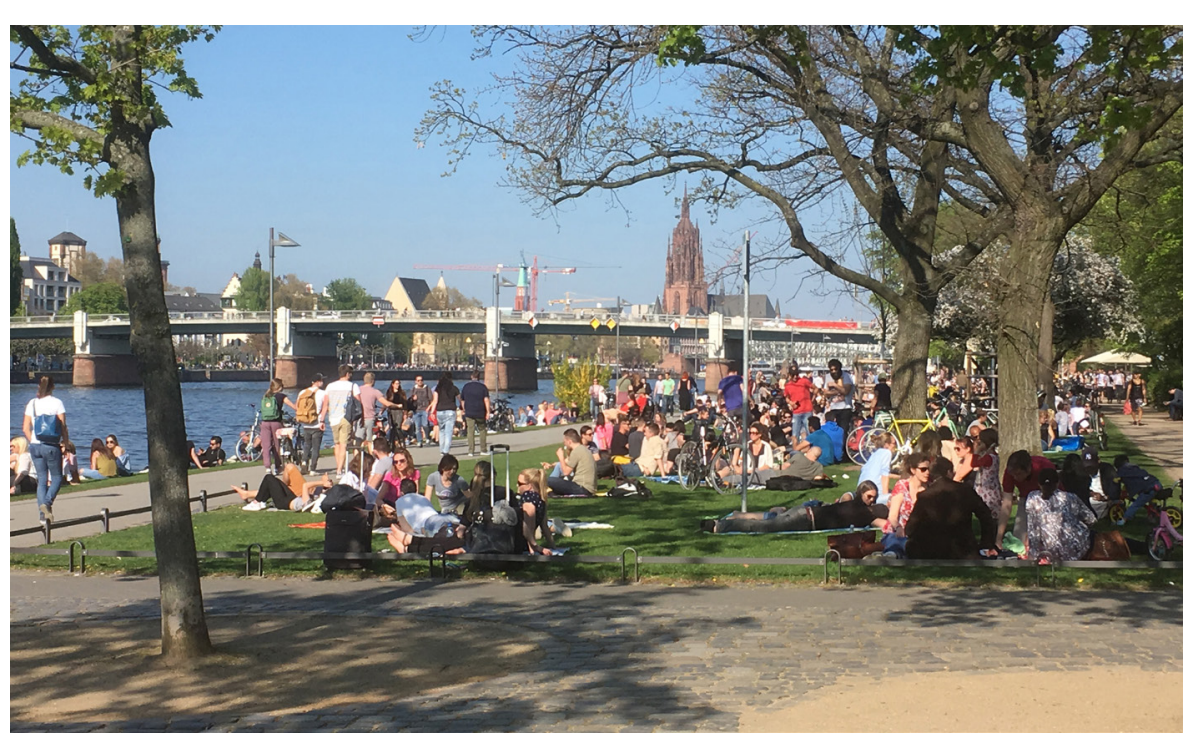

Fig. 8. Social spaces at Frankfurt am Main river embankment (c) Peterek 


\section{References}

Avan, D. (2020). Wie in Frankfurt die Wohnungsnot bekämpft werden soll. FAZ. NET, 2020/12/22. Retrieved from https://www.faz.net/aktuell/rhein-main/ frankfurt/frankfurt-durch-aufstockung-soll-die-wohnungsnot-bekaempftwerden-17113921.html (date of access: 2021/07/06).

Brand, U., Wissen, M. (2021). The Imperial Mode of Living. Everyday Life and the Ecological Crisis of Capitalism. London-New York: VERSO.

Breckner, I. (2018). Nachhaltige Stadtentwicklung. Sozialverträglichkeit und Umweltorientierung in der Stadtentwicklung. bpb Bundeszentrale für politische Bildung. Dossier: Stadt und Gesellschaft, 2018/07/09. Retrieved from https://www.bpb.de/politik/innenpolitik/stadt-undgesellschaft/216884/sozialvertraeglichkeit-und-umweltorientierung (date of access: 2021/07/06).

Bürklin, T., Peterek, M., Reichardt, J. (2021). In Case We Want to Survive. A Plea for an Architecture of Responsibility. Retrieved from https://www. climatehub.online (date of access: 2021/07/06/07).

Communication from the Commission. (2019). The European Green Deal. 2.1.5. Accelerating the shift to sustainable and smart mobility. Retrieved from https://eur-lex.europa.eu/legal-content/EN/TXT/?qid=1588580774040 \&uri=CELEX:52019DC0640 (date of access: 2021/07/06).

Cornelia Augustin Home Staging. (2021). Ich habe es am liebsten schön. Retrieved from https://www.cornelia-augustin.de (date of access: 2021/07/06).

Cuda, R. (2021). Bosco verticale, si fa presto a dire sostenibile. Le mie domande sui costi ambientali dei grattcieli. ilfattoquotidiano.it, 2021/02/13. Retrieved from https://www.ilfattoquotidiano.it/2021/02/13/boscoverticale-si-fa-presto-a-dire-sostenibile-le-mie-domande-sui-costiambientali-dei-grattacieli/6094643/ (date of access: 2021/07/06).

de Certeau, M. (1990). L'invention du quotidien. Tome 1: Arts de faire. Paris: Gallimard.

Hofmann, M.L., König, K. (2011). Der Gehry-Effekt. Eine architektursoziologische Studie über das MARTa Herford. Paderborn: Wilhelm Fink Verlag.

Janson, A., Bürklin, T. (2002). AuftritteScenes. Interaction with Architectural Space: the Campi of Venice. Basel-Boston-Berlin: Birkhäuser.

Klöckner, J. (2013). Wie grün sind Wälder auf Wolkenkratzern wirklich? In Mailand entsteht das erste Hochhaus mit Bäumen. Es ist leider nicht so grün, wie es scheint. WirtschaftsWoche, 2013/06/03. Retrieved from https://www.wiwo.de/technologie/green/staedtebau-wie-gruen-sindwaelder-auf-wolkenkratzern-wirklich/13546182.html (date of access: 2021/07/06).

Landry, C. (2008). The Creative City. A Toolkit for Urban Innovators. ${ }^{\text {nd }}$ Edition. London-Sterling, VA: Earthscan.

Leclerc, F. (2020). Viele unterschreiben für die Mainkai-Sperrung in Frankfurt. Frankfurter Rundschau, FR.de, 2020/04/16. Retrieved from https://www.fr.de/frankfurt/viele-unterschreiben-mainkai-sperrungfrankfurt-13653040.html (date of access: 2021/07/06).

Lefebvre, H. (2000). La production de l'espace. $4^{\text {th }}$ Edition. Paris: Anthropos.

Lindner, R. (2021). Powerpaar schenkt New York neue Attraktion. Frankfurter Allgemeine Zeitung, 2021/05/02.

Lynch, K. (1960). The Image of the City. Cambridge-Massachussets: MIT Press \& Harvard University Press.

Mühl, M. (2021a). Unser digitaler faustischer Pakt. Frankfurter Allgemeine Zeitung, 2021/05/26.

Mühl, M. (2021b). SchönerWohnen für acht Millionen Euro. FAZ.NET, 2021/05/06. Retrieved from https://www.faz.net/aktuell/feuilleton/debatten/wie-diepandemie-das-wohnen-der-reichen-veraendert-hat-17327037.html (date of access: 2021/07/06). 
Nobis, C., Kuhnimhof, T. (2018). Mobilität in Deutschland. MiD Ergebnisbericht. Studie von infas, DLR, IVT und infas $360 \mathrm{im}$ Auftrag des Bundesministers für Verkehr und digitale Infrastruktur (FE-Nr. 70.904/15). Bonn-Berlin: Bundesministerium für Verkehr und digitale Infrastruktur. Retrieved from www.mobilitaet-in-deutschland.de (date of access: 2021/07/06).

Reckwitz, A. (2021). Die Gesellschaft der Singularitäten. $4^{\text {th }}$ Edition. Berlin: Suhrkamp Verlag.

Rossi, A. (1966). L'architettura della città. Padova: Marsilio Editori.

Schellnhuber, H.J. (2021). Bauhaus für die Erde. Ein bescheidener Vorschlag zur Rettung der Welt: Wenn wir unsere Städte aus Holz statt aus Beton bauen, bleibt uns das Schlimmste erspart. Frankfurter Allgemeine Zeitung, $2021 / 04 / 22$.

Schulze, G. (2000). Die Erlebnisgesellschaft. Kultursoziologie der Gegenwart. $8^{\text {th }}$ Edition. Frankfurt am Main-New York: Campus.

Seghetti, E. (2020). Il grattacielo che diventa foresta verticale: vera sostenibilità o solo moda? green.it. Retrieved from https://www.green.it/grattacieloforesta-verticale/ (date of access: 2021/07/06).

Sitte, C. (1909). Der Städtebau nach seinen künstlerischen Grundsätzen. $4^{\text {th }}$ Edition. Wien: Karl Graeser \& $K^{\text {ie }}$.

Stadt Wien (n.d.). Smart City Wien. Retrieved from https://www.wien.gv.at/ stadtentwicklung/projekte/smartcity/index.html (date of access: 2021/07/06).

United Nations (2015). The 17 Goals. Department of Economic and Social Affairs. Sustainable Development. Retrieved from https://sdgs.un.org/goals (date of access: 2021/07/06).

Welzbacher, C. (2021). Grüne Architektur oder grüne Märchen? Deutsches Architektenblatt, May 2021, 17-21. 